\title{
THE IMPLEMENTATION OF AUTOMATIC SPRAYER IN FARMING GROUP IN KUTA DAME VILLAGE
}

Abstract - The majority of people in Kuta Dame Village work as farmers. Several outreaches

\author{
${ }^{1}$ Bakti Dwi Waluyo*, ${ }^{1}$ Eka Dodi Suryanto, ${ }^{1}$ Amirhud Dalimunthe, ${ }^{2}$ Restu \\ ${ }^{1}$ Department of Electrical Engineering Education, Universitas Negeri Medan, Medan, Indonesia \\ ${ }^{2}$ Department of Geography Education, Universitas Negeri Medan, Medan, Indonesia \\ * Corresponding email: bakti_dw@unimed.ac.id
}

have been carried out to develop the agricultural sector in Kuta Dame village. However, some of the extension services rarely touched on effective technology to support agriculture in Kuta Dame village. One of the technologies that need to be developed by the Kuta Dame village farmer group in supporting agriculture is an automatic sprayer. This development is necessary because most farmers are still using the carrying type sprayer with a manual pump (diaphragm pump). The sprayer's diaphragm pump pressure produces a relatively low spray pressure, especially when the operator is tired of moving the pump lever. As a result, the spraying performance is not perfect, making the spray grains not smooth and not reaching the leaf surface evenly. A community service program was implemented to implement automatic sprayers for farmers in Kuta Dame village. This community service program aims to carry out the planning process and use of an electric sprayer appropriately to increase spraying fertilizers and pesticides on crops. Implementing this community service activity starts from planning activities, implementing academic counseling, implementing the practice, handing over an electric sprayer, monitoring, and satisfaction analysis.

\section{Keywords-Appropriate Technology, Automatic Sprayer, Technology for Agriculture}

\section{INTRODUCTION}

The Kuta Dame village farmer group is located in the Kerajaan sub-district, situated in the Pakpak Bharat districts. Kuta Dame village has an area $18.00 \mathrm{Km}^{2}$, or about $12.17 \%$ ratio to the Kerajaan sub-district size with a population of 2,311 people [1]. The condition of the Kuta Dame village area is generally hilly and is above an altitude of 500 meters to 1,400 meters above sea level [2]. Most of the population in Kuta Dame village work as farmers. Agricultural commodities that are often grown on agricultural land are rice, corn, green beans, peanuts, and red chilies [3].

Several pieces of training related to agriculture have been carried out by the government to increase agricultural commodities' potential. However, some of the training pieces that have 
been conducted are still not focused on developing appropriate technology to support agriculture. As a result, farmers are always less effective in developing their livelihoods.

So far, the Kuta Dame village farmer group conducting spraying treatments for plants is carried out using a carrying type sprayer with a manual pump or a diaphragm pump with a lever that is moved up and down the operator's left arm. The sprayer's diaphragm pump pressure produces a relatively low spray pressure, especially when the operator is tired of moving the pump lever. From the observation, the spraying performance is not perfect, and the spray grains are not smooth and do not reach the leaf surface evenly [4]. Besides, using this manual sprayer, the operator can only spray one row of plants in one operation path, so the target area of land applied in the allotted time cannot be achieved [5].

Based on this problem, automatic sprayers was applied for agriculture in Kuta Dame village. With the application of appropriate technology, it is expected to assist farmer groups in increasing agricultural products' productivity so that it has a good impact on improving the welfare of farmer group members [6].

To support these activities, farmers in Kuta Dame village collaborated with the Institute for Research and Community Service (LPPM) Universitas Negeri Medan to organize a community partnership program (PKM) that focuses on developing appropriate technology for farming communities.

\section{METHOD}

The approach method for applying automatic sprayer technology to the Kuta Dame village farmer group starts from the activity planning stage, technical implementation, and activity evaluation. This program also provides counseling through periodic assistance to members of the Kuta Dame village farmer group.

\subsection{Activity Planning}

At this stage, the following planning activities carried out:

1. Survey the condition of the community in Kuta Dame village. 
2. Analyzing the problems in Kuta Dame village, especially with the development of appropriate technology for the agricultural sector.

3. Analyzing the solution to existing issues according to the needs of the community in Kuta Dame village.

4. Coordinate with a farmer community group in Kuta Dame village to prepare the PKM program to solve existing problems.

\subsection{Technical Implementation}

In the context of applying appropriate technology to the Kuta Dame village farmer group, the technical implementation is as follows:

1. Prepare community service activities related to applying appropriate technology, namely automatic sprayer for farmers in Kuta Dame village.

2. Analyzing the need to support outreach activities carried out for farmers in Kuta Dame village.

3. The community service team will provide a glimpse theoretical overview of the use of appropriate technology in agriculture. In this theory, too, the Kuta Dame village farmer group will be gathered in one place to be given a theoretical explanation of the description of the community service program. The delivery method is by way of presentation, discussion, question, and answer.

4. Prepare materials and tools to assist farmers in Kuta Dame village in using an automatic sprayer.

5. The PKM Team will provide direct assistance to the Kuta Dame village farmers regarding using an automatic sprayer.

6. Members of the Kuta Dame Village farmers were allowed to practice using an automatic sprayer.

7. At the end of the practice will be evaluated.

8. Hand over automatic sprayers to members of the Kuta Dame village farmers.

9. Implementation of automatic spraying on agricultural land belonging to a member of farmers named Syahrul Kabeakan.

\subsection{Evaluation}


At this stage, the PKM team evaluated applying the automatic sprayer to the Kuta Dame village farmer group. This evaluation activity aims to monitor PKM activities regarding applying appropriate technology, namely automatic sprayers for agricultural land in Kuta Dame village. PKM team can use the monitoring results as a reference basis for analyzing constraints in PKM activities. Also, monitoring activities can use to analyze the level of satisfaction with the implementation.

\section{RESULT AND DISCUSSION}

PKM is implemented in the agricultural area of the Kuta Dame village farmer group. This program is carried out in counseling on automatic sprayers to support agriculture in the village of Kuta Dame. The following are the stages of implementing an automatic sprayer, namely:

\subsection{Activity Planning}

An initial survey was carried out related to agricultural technology currently used by the Kuta Dame village farmer group. The results show that the technology used by farmers is still manual. Thus, this raises several problems, such as the ineffectiveness of the technology used. One technology that is still manual is the plant sprayer. The use of a manual sprayer causes uneven spray results. Also, this technology causes fatigue for its users. Therefore, it is necessary to innovate an automatic sprayer that can solve the Kuta Dame village farmer groups' problems.

Based on the analysis of these problems, LPPM and the Kuta dame village farmer group coordinated to carry out community service activities related to automatic sprayers' application. This community service activity was held by involving several students in the implementation process.

\subsection{Implementation of Activities}

The PKM implementation team prepares the materials and materials used for the application of automatic sprayers. The equipment provided for this service activity is water pumps, automatic sprayers, and repair maintenance equipment. The kit can be seen in Figure 1. 

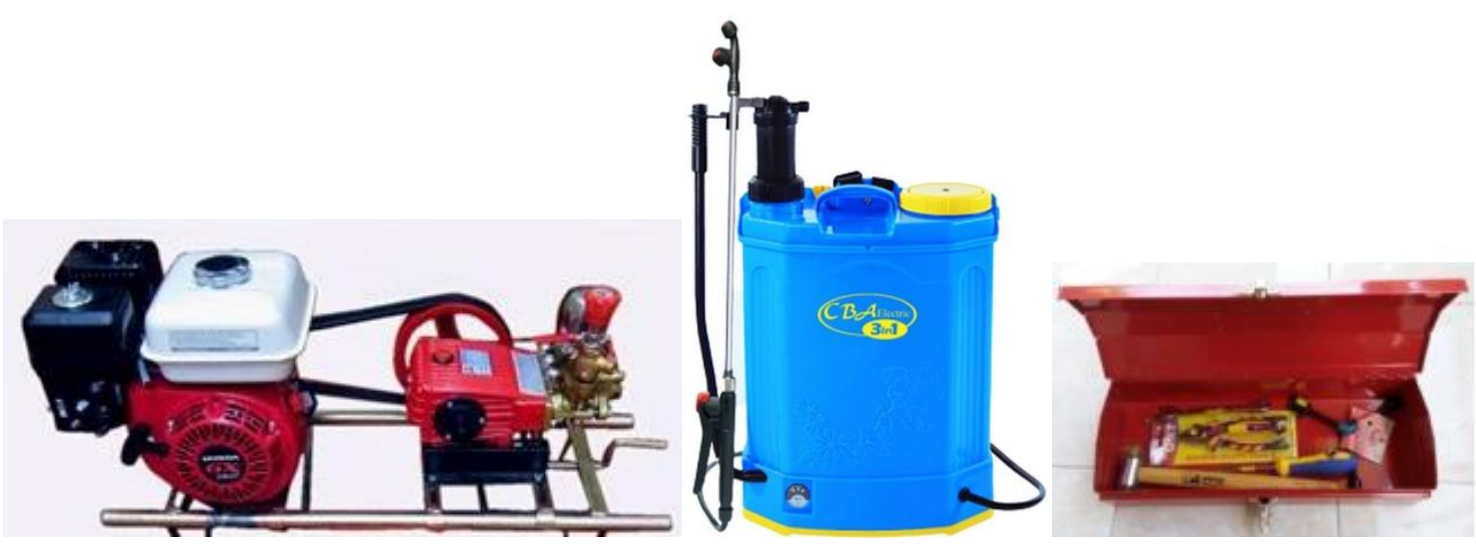

Figure 1. Types of equipment and materials for PKM

In the early stages, members of the farmer group obtain materials related to applying appropriate technology for agriculture. Bakti Dwi Waluyo carried out the delivery of this material. In the next stage, members of the farmer group received counseling related to the use and maintenance of automatic sprayers delivered by Eka Dodi Suryanto. After all the materials are explained, the next stage of implementation is using and maintaining automatic sprayers. At this stage, students are involved in assisting in the use and maintenance of automatic sprayers.
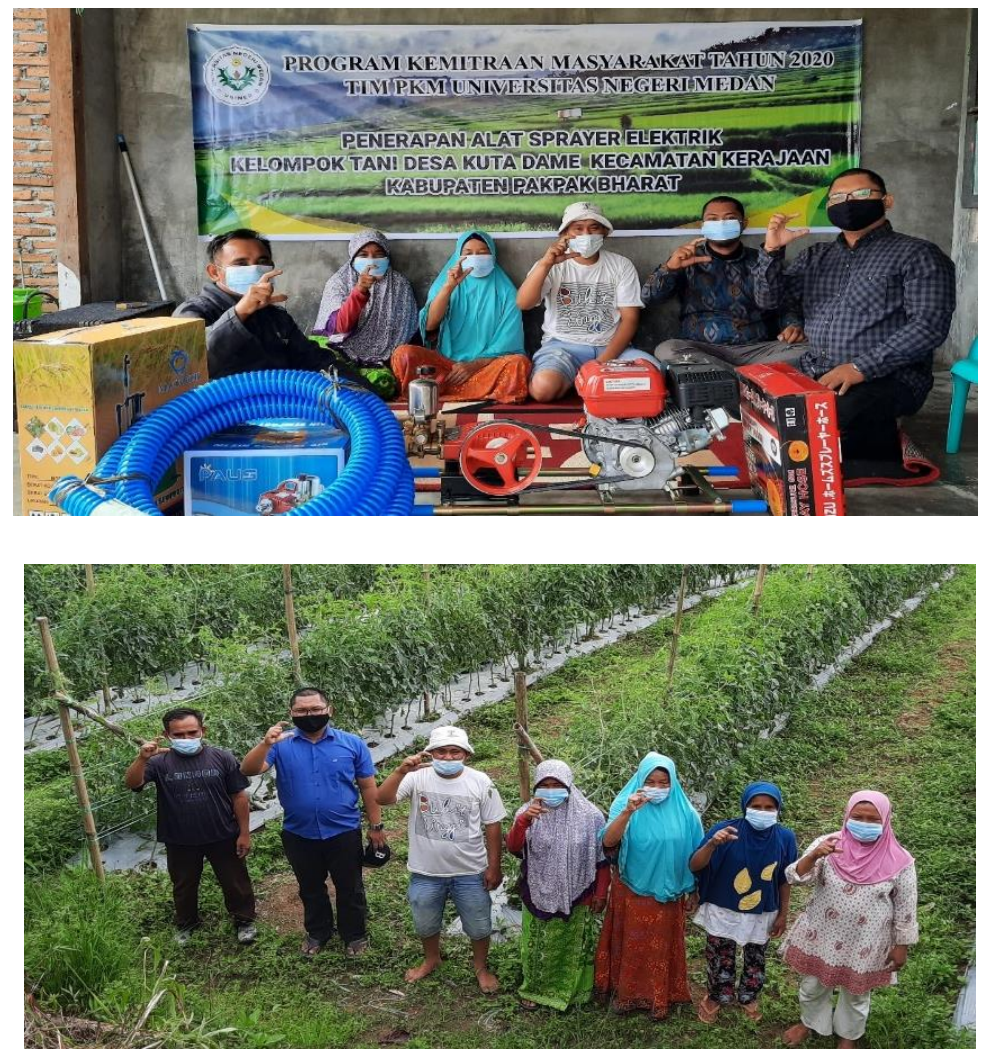

Figure 2. Documentation of PKM activities 
Furthermore, the PKM team provided instructions for the operation and maintenance of water pump machines and automatic sprayers. Documentation of activities can be seen in Figure 2 . Extension material for process and maintenance of water pump machines are:

1. The working principle of the pump engine drive,

2. The working principle of the water pump,

3. The main components of the engine and water pump,

4. Water pump machine operating procedure,

5. Water pump engine maintenance procedures.

The materials for the operation and maintenance of the automatic sprayer are:

1. Automatic sprayer working principle,

2. Automatic spray components,

3. Automated spray operation procedure,

4. Automated spray treatment procedure.

Several extension participants were very enthusiastic about this activity. Many participants raised questions regarding how to use and maintain this automatic sprayer. Likewise, during the mechanical sprayer trial process, the results showed that the automated spraying technology solved manual sprayers' problem, where the automatic sprayer had a more even spray quality.

\subsection{Evaluation and Monitoring of Activities}

The PKM team evaluated applying the automatic sprayer to determine the level of satisfaction of members of the Kuta Dame village farmer group in participating in activities from beginning to end. Based on the evaluation of 15 members of the farmer group, most of the participants were very satisfied with this activity. The graph of participant satisfaction with automated sprayer activity can be seen in Figure 3. 


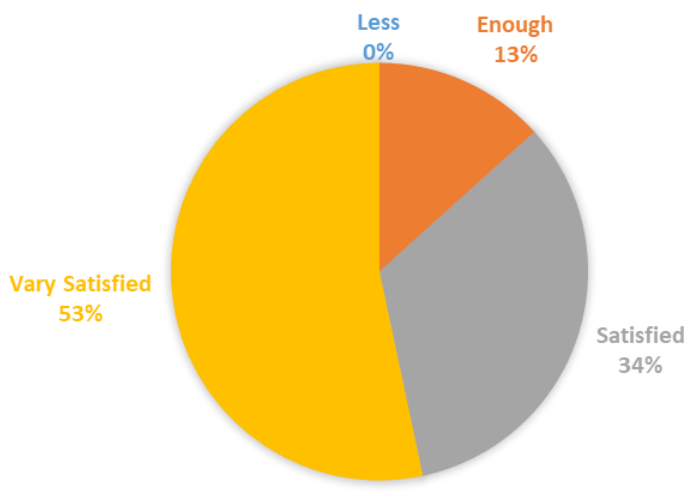

Figure 3. The response to the level of participant satisfaction in the automatic automatic sprayer

Based on Figure 3, 8 out of 15 farmer group members who attended the counseling stated they were delighted. Meanwhile, five people said they were satisfied, and two people said they were quite satisfied. From these results, it can be concluded that the Kuta Dame village farmer group members are happy with the activities that have been carried out. However, the monitoring and assistance process still needs to be done. The aim is to observe the development of automatic sprayers in supporting agriculture in the village of Kuta Dame.

\section{CONCLUSION}

The 2020 community partnership program activities can solve problems in the Kuta Dame village farmer groups. In general, PKM with the theme of applying this automatic sprayer has the following results:

1. Appropriate technology in automatic sprayers is used to support the agricultural sector in Kuta dame village.

2. We are increasing the understanding of members of the Kuta Dame village farmer group on the importance of appropriate technology innovation.

The community is expected to develop automated sprayer technology using solar power as an electricity source to increase technological innovation.

\section{REFERENCES}

[1] Badan Pusat Statistik Kabupaten Pakpak Bharat. 2019. Kabupaten Pakpak Bharat Dalam Angka. (https://pakpakbharatkab.bps.go.id/)

[2] Rencana Pembangunan Jangka Menengah Daerah (RPJMD) Kabupaten Pakpak Bharat 2016-2021

[3] Pekerjaan Bantuan Teknis RPIJM Kabupaten Pakpak Bharat 2015-2019

[4] M.N. Rahman dan M. Yamin. 2014. Modifikasi Nosel pada Sistem Penyemprotan untuk 
Pengendalian Gulma Menggunakan Sprayer Gendong Elektrik, Jurnal Keteknikan Pertanian, Vol. 2, No. 1, April 2014.

[5] G.W. Utomo. 2013. Perancangan dan Pembuatan Sprayer Pupuk Elektrik, Tugas Akhir. Juli 2013.

[6] Muas M, Muh. Rusdi, \& Syaharuddin Rasyid. 2017. Penerapan Mesin Pompa Air dan Penyemprot Hama pada Kelompok Tani Penggarap Sawah di Gentungang. Prosiding Seminar Hasil Pengabdian Kepada Masyarakat (SNP2M); ISSN: 978-602-60766-2-5 